\title{
Saltwater Intrusion in the Floridan Aquifer System Near Downtown Brunswick, Georgia, 1957-2015
}

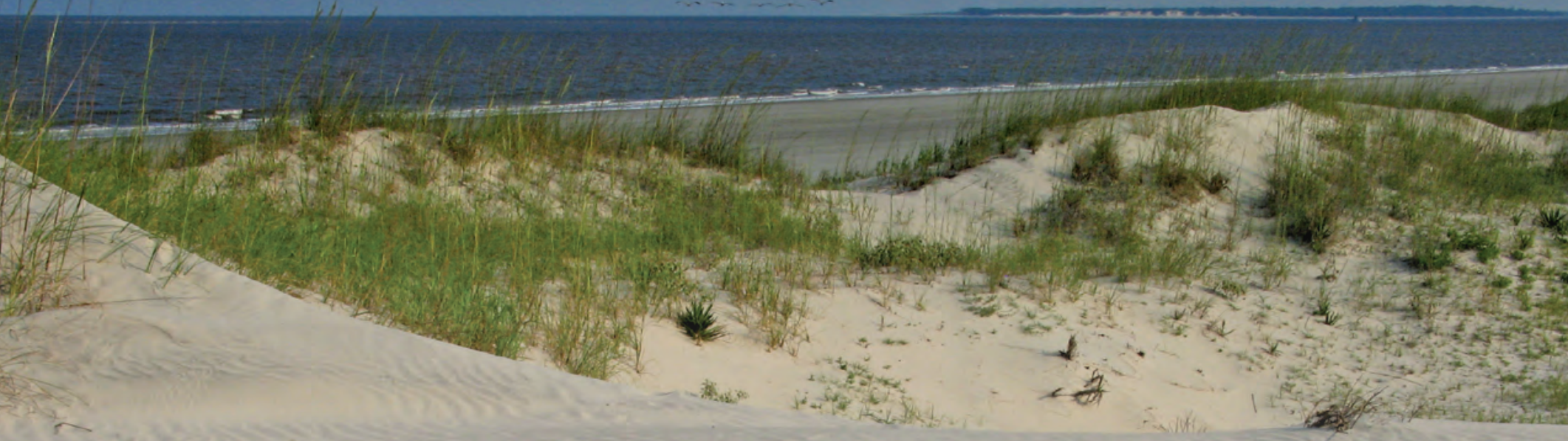

\section{Introduction}

The Floridan aquifer system (FAS) consists of the Upper Floridan aquifer (UFA), an intervening confining unit of highly variable properties, and the Lower Floridan aquifer (LFA). The UFA and LFA are primarily composed of Paleocene- to Oligocene-age carbonate rocks that include, locally, Upper Cretaceous rocks (Miller, 1986; Krause and Randolph, 1989). The FAS extends from coastal areas in southeastern South Carolina and continues southward and westward across the coastal plain of Georgia and Alabama, and underlies all of Florida. The thickness of the FAS varies from less than 100 feet (ft) in aquifer outcrop areas of South Carolina to about 1,700 ft near the city of Brunswick, Georgia (Williams and Kuniansky, 2015).

Locally, in southeastern Georgia and the Brunswick-Glynn County area, the UFA consists of an upper water-bearing zone (UWBZ) and a lower water-bearing zone (LWBZ), as identified by Wait and Gregg (1973), with aquifer test data indicating the upper zone has higher productivity than the lower zone. Near the city of Brunswick, the LFA is composed of two permeable zones: an early middle Eocene-age upper permeable zone (UPZ) and a highly permeable lower zone of limestone (LPZ) of Paleocene and Late Cretaceous age that includes a deeply buried, cavernous, saline water-bearing unit known as the Fernandina permeable zone (Krause and Randolph, 1989).
Maslia and Prowell (1990) inferred the presence of major northeast-southwest trending faults through the downtown Brunswick area based on structural analysis of geophysical data, northeastward elongation of the potentiometric surface of the UFA, and breaches in the local confining unit that influence the area of chloride contamination. Pronounced horizontal and vertical hydraulic head gradients, caused by pumping in the UFA, allow saline water from the FPZ to migrate upward into the UFA through this system of faults and conduits.

Saltwater was first detected in the FAS in wells completed in the UFA near the southern part of the city of Brunswick in late 1957 (Wait, 1965). By the 1970s, a plume of groundwater with high chloride concentrations had migrated northward toward two major industrial pumping centers, and since 1965, chloride concentrations have steadily increased in the northern part of the city (fig. 1). In 1978, data obtained from a 2,720-ft-deep test well (33H188; fig. 2) drilled south of the city showed water with a chloride concentration of 33,000 milligrams per liter $(\mathrm{mg} / \mathrm{L})$, suggesting the saltwater source was located below the UFA in the Fernandina permeable zone (FPZ) of the LFA (Jones and others, 2002).

All U.S. Geological Survey (USGS) data collected for this study, including groundwater levels in wells and water-chemistry data, are available in the USGS National Water Information System (U.S. Geological Survey, 2016). 


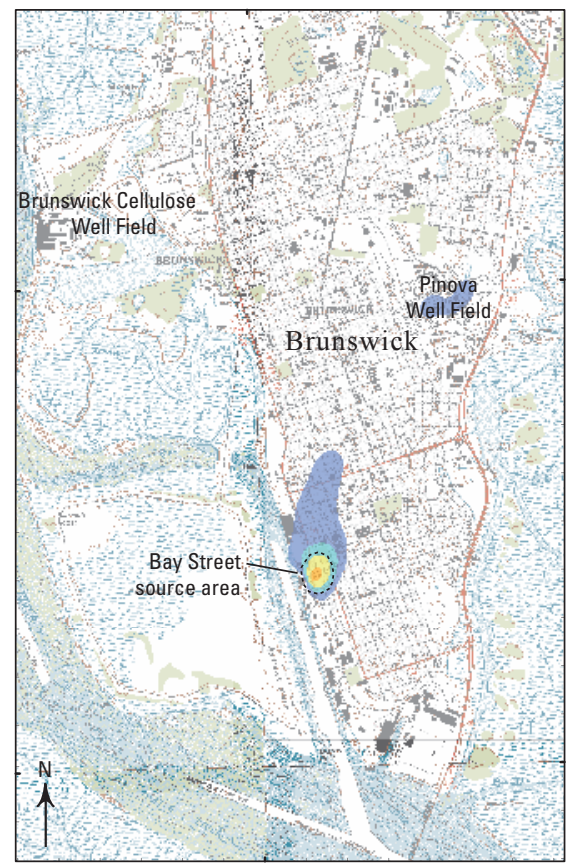

June 2000
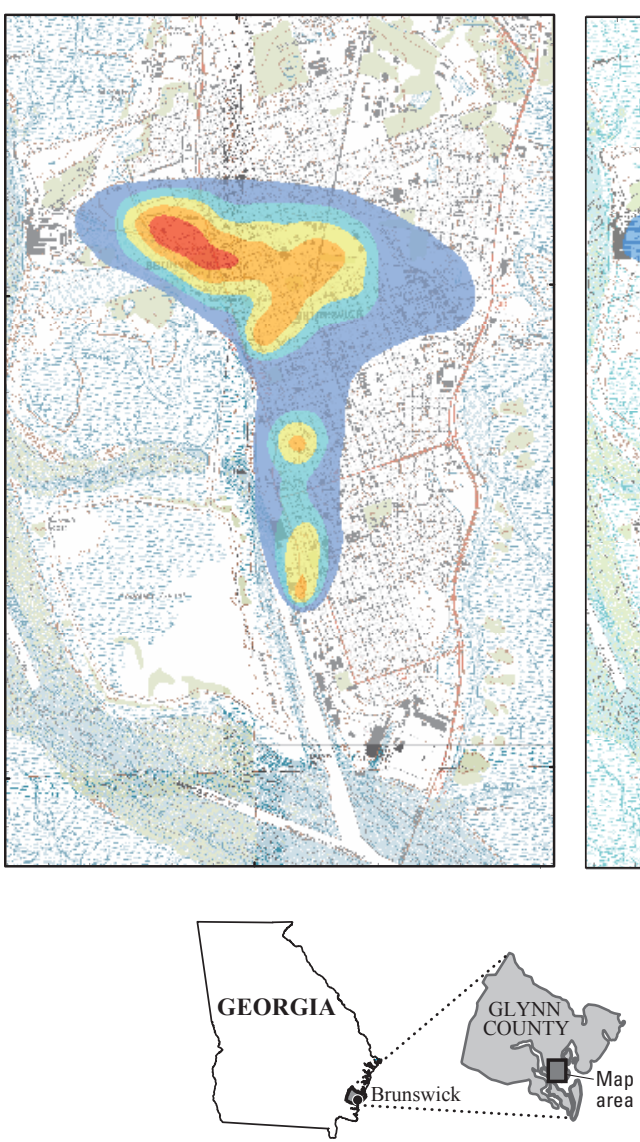

January 1970-January 1971

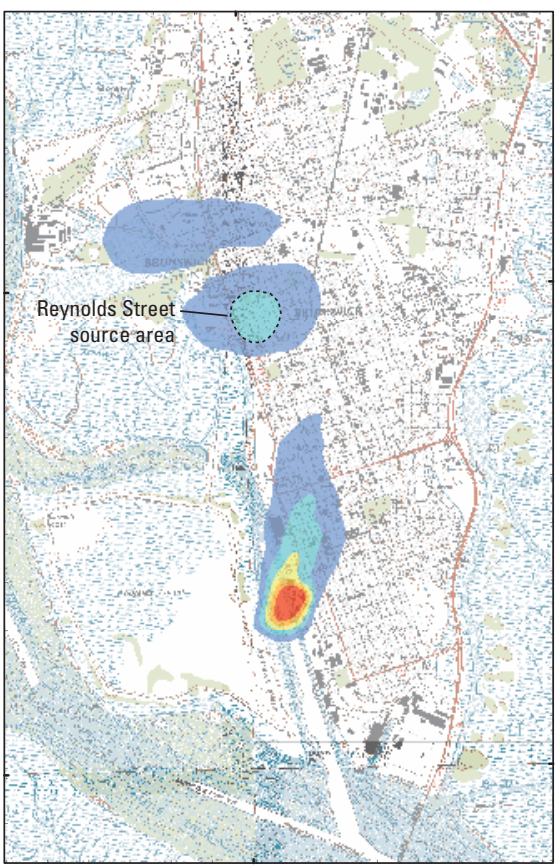

October 2014

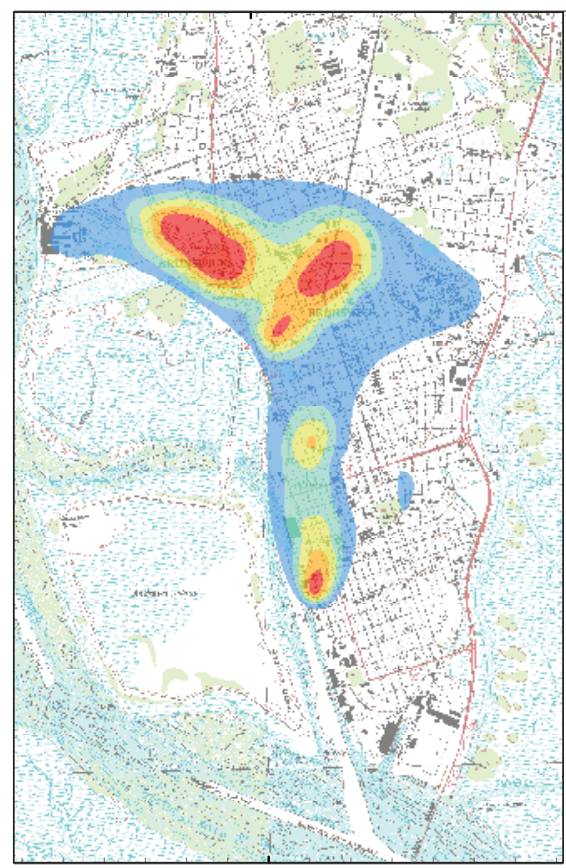

March-June 1980

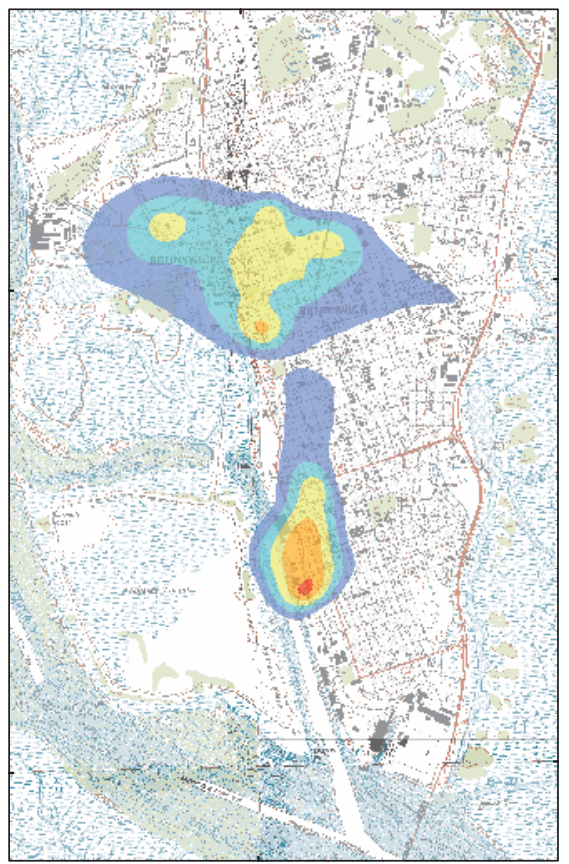

October 2015

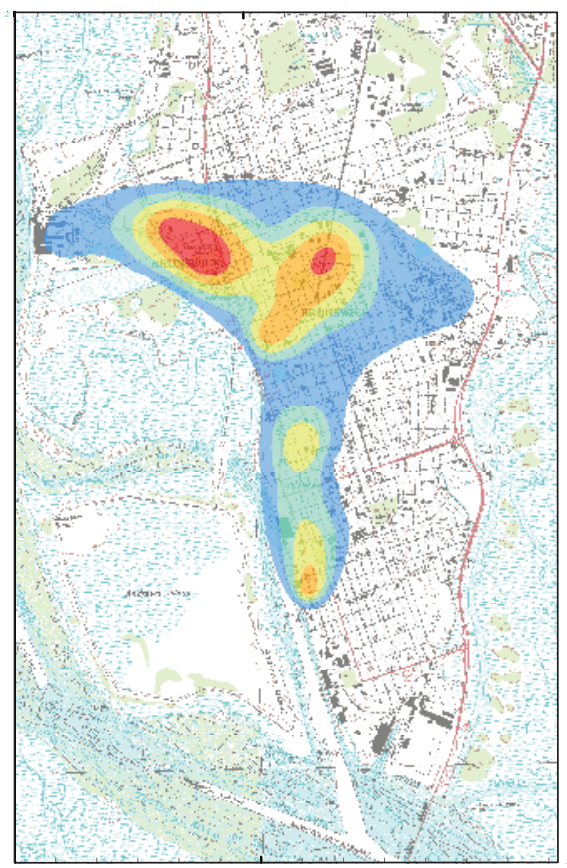

EXPLANATION

Chloride concentration, in milligrams per liter
$\square<250 \quad \square \quad 750$ to $1,250 \quad \square 1,750$ to 2,250
$\square 250$ to $750 \quad \square 1,250$ to $1,750 \quad \square>2,250$

Figure 1. Chloride concentration in the upper water-bearing zone of the Upper Floridan aquifer in Brunswick, Georgia. 

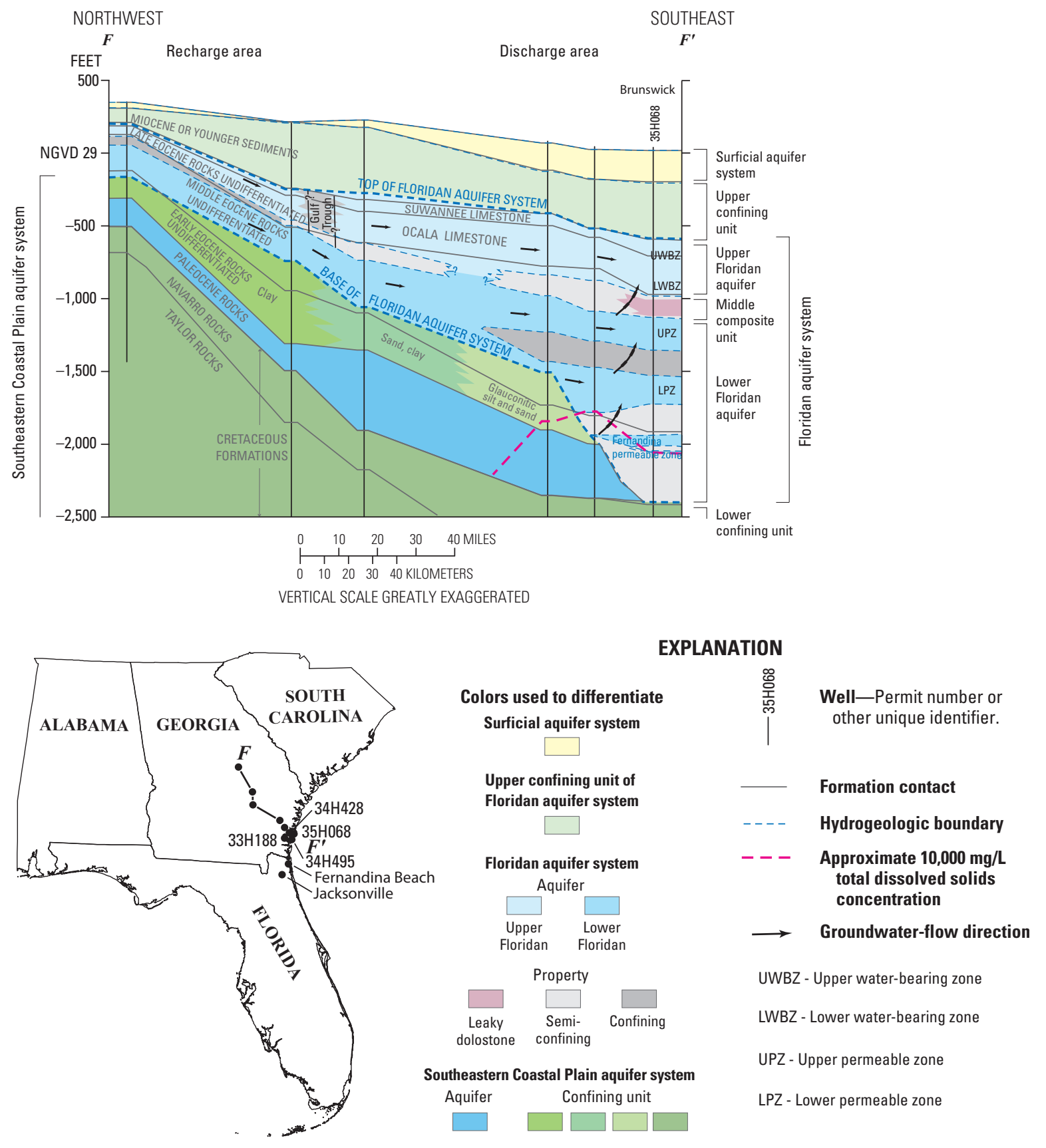

Figure 2. Generalized hydrogeologic cross section $F-F^{\prime}$ and groundwater-flow directions (modified from Williams and Kuniansky, 2015). 


\section{Groundwater Levels, Groundwater Pumping, and Flow in the Floridan Aquifer System}

Prior to development of the UFA in the late 1800s, groundwater levels in the Brunswick area were estimated to be as high as $55 \mathrm{ft}$ above land surface [ $65 \mathrm{ft}$ above the North American Vertical Datum of 1988 (NAVD 88)] and groundwater flow was in an easterly direction toward the coast (Johnston and others, 1980). Since that time, the UFA has become a major source of water supply for industrial and municipal use along coastal Georgia, including Glynn County and the city of Brunswick. In Glynn County, large withdrawals began in the early 1940s, mostly by industry, and increased by 11.6 million gallons per day $(\mathrm{Mgal} / \mathrm{d})$ between 1950 and 1960 to a reported total of $55.3 \mathrm{Mgal} / \mathrm{d}$ during 1960 (Cherry and others, 2011). Groundwater use peaked in the early 1980 s with reported average annual pumping rates of 58.8 and $19.5 \mathrm{Mgal} / \mathrm{d}$ at Brunswick Cellulose Inc. and Pinova Inc. (formerly Hercules Inc.), respectively, and an average annual pumping rate of $9.8 \mathrm{Mgal} / \mathrm{d}$ (fig. 3) for public supply (Krause and Randolph, 1989; Jones, 2001).

A steady increase in pumping since predevelopment caused groundwater-level declines in the UFA ranging from $20 \mathrm{ft}$ in southernmost Glynn County to as much as $80 \mathrm{ft}$ near pumping centers in northern Brunswick. This increase altered the natural groundwater-flow direction from eastward toward the coast to north and northeast toward the center of pumping in Brunswick (Jones, 2001). Groundwater use near the city of Brunswick has steadily declined since 1990 . Water conservation measures in effect during late 2011 at the Brunswick Cellulose well field reduced pumping from about $35 \mathrm{Mgal} / \mathrm{d}$ to $23.3 \mathrm{Mgal} / \mathrm{d}$ during 2015 (S. Swan, Brunswick-Glynn County Joint Water and Sewer Commission, written commun., August 2015). A similar decline in groundwater use occurred at the Pinova well field, with a reduction in pumping from about $6 \mathrm{Mgal} / \mathrm{d}$ in 2010 to $4.2 \mathrm{Mgal} / \mathrm{d}$ during 2015. Pumping for public supply in Brunswick-Glynn County also decreased slightly from $9.8 \mathrm{Mgal} / \mathrm{d}$ during 1980 to $9.3 \mathrm{Mgal} / \mathrm{d}$ in 2015. Groundwater use from the UFA for public supply in Brunswick-Glynn County declined despite an increase in population from 54,980 persons in 1980 to 83,579 in July 2015 (U.S. Census Bureau, 2015).

Water levels in the UWBZ of the UFA (well 34H328; fig. 3) are primarily influenced by changes in pumping. The early part of the record from 1939 to 1948 indicates that water levels were about $40 \mathrm{ft}$ above NAVD 88. Over the following 30 years, as pumping increased, water levels declined by more than $30 \mathrm{ft}$, and a cone of depression formed near the industrial well fields in the northern part of Brunswick. This period was followed by a recovery in water levels in the early 1980s, when industrial groundwater users reduced pumping by $23.5 \mathrm{Mgal} / \mathrm{d}$. Since the mid-1980s, water levels in well 34H328 have ranged between 8.5 and $14.3 \mathrm{ft}$ above NAVD 88. During the peak of groundwater use in the early 1980s, the water levels in the UFA were near sea level (NAVD 88) in the northern part of the Brunswick area and about $15 \mathrm{ft}$ below NAVD 88 near the industrial well fields (Johnston and others, 1980).

During October 2015, water levels from continuous recorders and synoptic water-level measurements were collected from 50 wells completed in the UWBZ of the UFA. The potentiometric surface map (fig. 4) constructed using these water-level data indicates the general direction of groundwater flow is from the southwest in neighboring Camden and Brantley Counties towards the northeast across Glynn County and into McIntosh County. The water-level contours indicate that a portion of groundwater flow is captured and directed toward pumping centers in northern Brunswick. This captured flow is evident from the 15- and 10-ft contours that surround the pumping centers, indicating groundwater flow toward downtown Brunswick from the southwest, the southeast, and

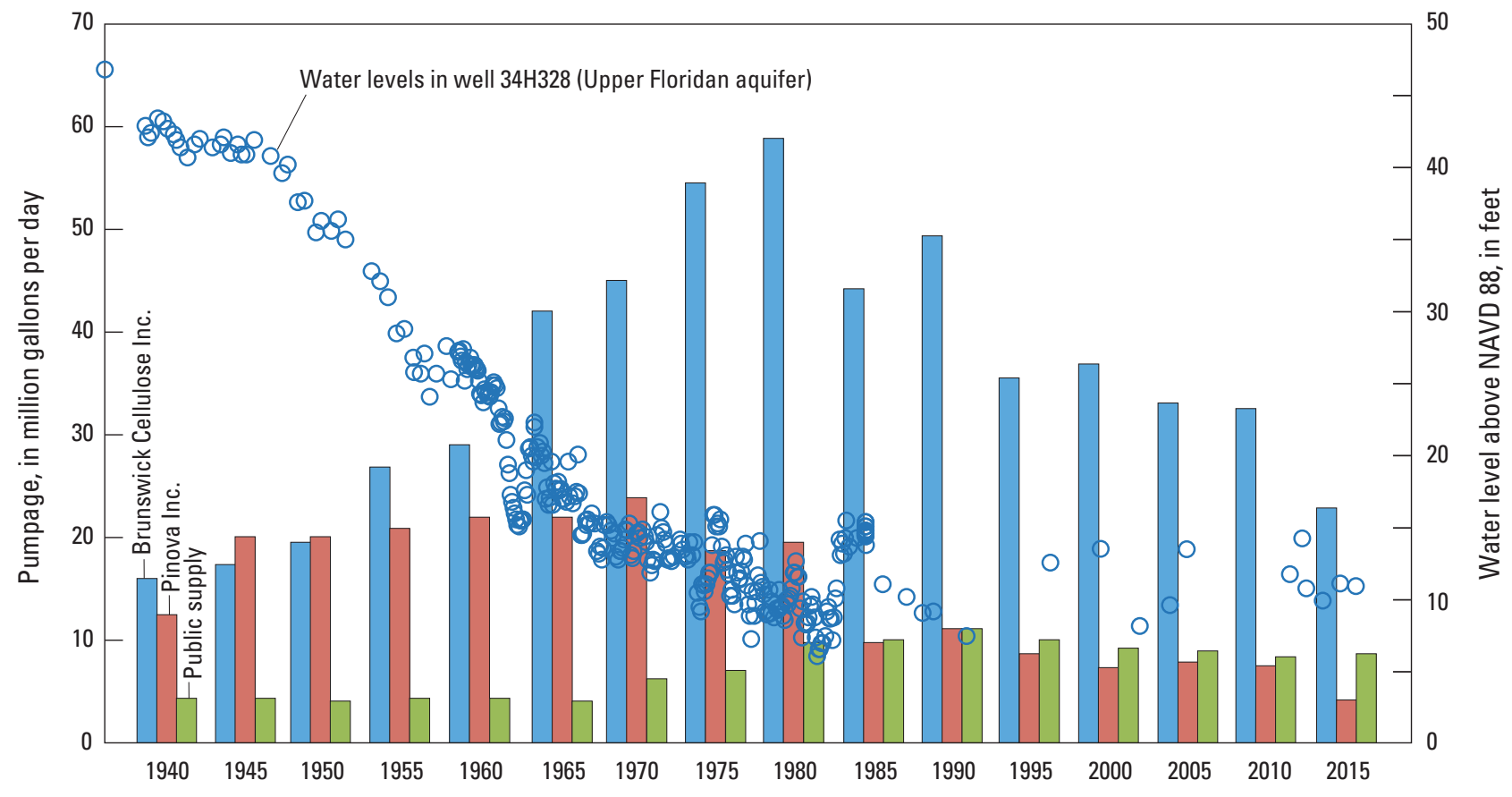

Figure 3. Major groundwater pumpage from the Upper Floridan aquifer in the Brunswick-Glynn County area, Georgia, 1940-2015 and water levels in well 34H328, 1939-2013 (see fig. 2 for well location). 
the north. The map of downtown Brunswick (inset, fig. 4) shows the 10-ft contour covering the northwest part of the city near the Brunswick Cellulose well field, which is an indication of the continued presence of a cone of depression caused by pumping. However, when compared to previous contour maps, the October 2015 potentiometric contours near the Brunswick Cellulose well field indicate that water levels have increased since the peak of pumping during 1980.

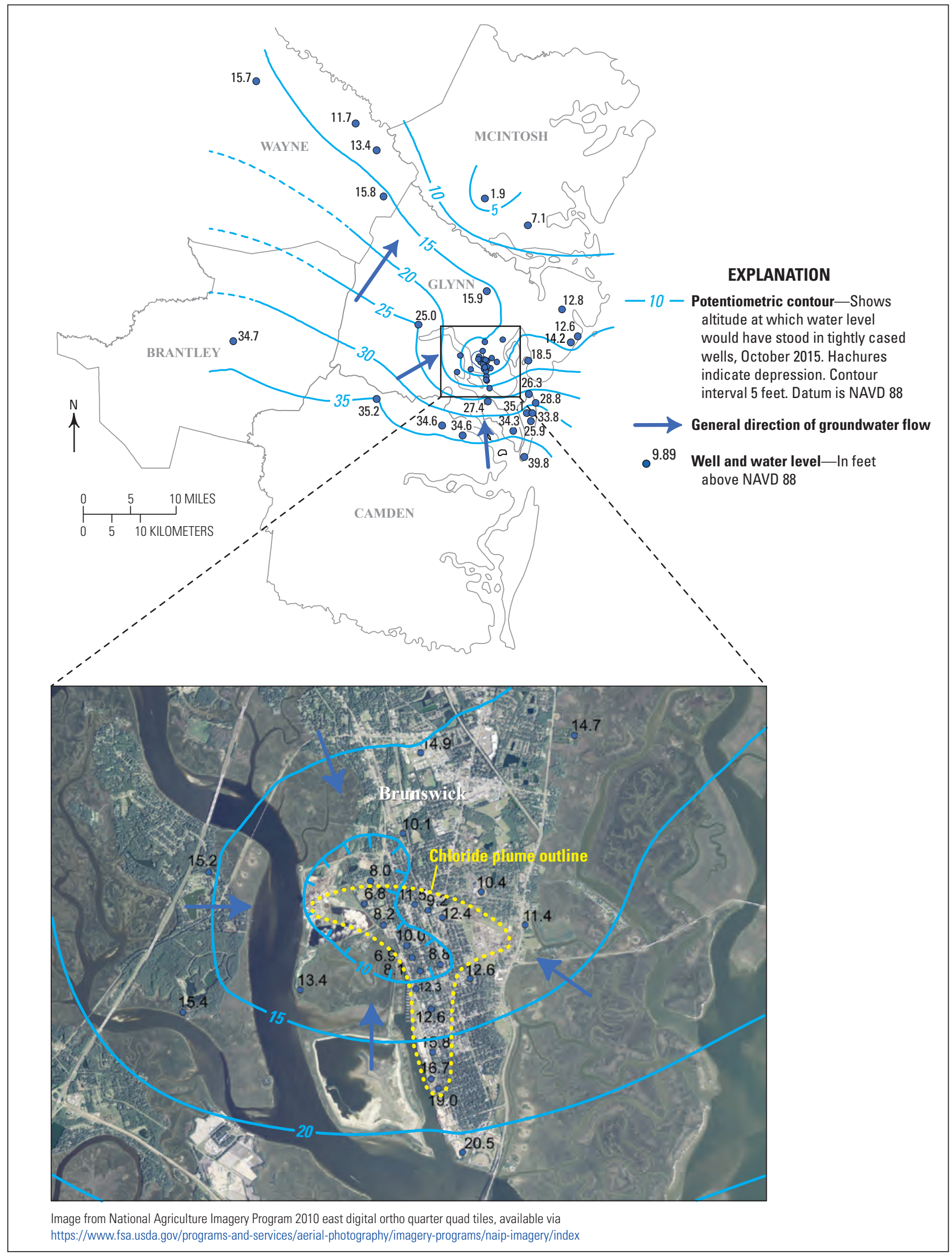

Figure 4. Potentiometric surface of the Upper Floridan aquifer, Brunswick-Glynn County, Georgia, October 19-22, 2015. 


\section{Chloride Concentrations in the Upper Floridan Aquifer}

The area of chloride contamination in the UWBZ of the UFA near the city of Brunswick during October 2015 was mapped using groundwater samples collected from 33 wells. The chloride concentration in an approximate 2-square-mile area near the city of Brunswick was greater than the $250-\mathrm{mg} / \mathrm{L}$ State and Federal secondary maximum contaminant level (SMCL) (Georgia Environmental Protection Division, 1997; U.S. Environmental Protection Agency, 2000) and exceeded $2,250 \mathrm{mg} / \mathrm{L}$ in part of the area (fig. 1). The extent of chloride concentrations shown on the October 2014 and 2015 maps is similar to the extent shown on the map published for 2000 (Hamrick and Cherry, 2015), with areas of highest chloride concentration found in the northern part of the city, as well as near the Bay Street source area in the southern part of the city (fig. 1). The potentiometric surface map (fig. 4) of the UWBZ of the UFA near downtown Brunswick indicates that the groundwater-flow direction is northwest from the Reynolds Street source area (fig. 1) toward the Brunswick Cellulose well field. The long-term changes in chloride concentration are consistent with the primary groundwater-flow direction, which controls the lateral movement of chloride from the Bay Street source area (fig. 1) toward the north and then from the Reynolds Street source area toward the industrial well fields. Low horizontal hydraulic head gradients in the UWBZ of the UFA toward the Pinova well field, or another source of chloride contamination, possibly allow an area of elevated chloride concentrations to extend to the northeast from the Reynolds Street source area.

A comparison of results from separate groundwater samples collected during October 2014 and October 2015, in 12 wells open to the UWBZ of the UFA, indicates a maximum increase in chloride concentration of $8.8 \mathrm{mg} / \mathrm{L}$ and a maximum decrease of $390 \mathrm{mg} / \mathrm{L}$ (fig. $5 \mathrm{~A}$ ). The outline of the chloride plume is shown in figure $5 A$ for the UWBZ of the UFA. The maximum decrease in chloride concentrations was reported in well 34H393 (390 mg/L), located within the Bay Street source area. Increases in chloride concentrations were limited to $8.8 \mathrm{mg} / \mathrm{L}$ in well $34 \mathrm{H} 344$, located south of the Pinova well field. Chloride concentrations in the northern part of the chloride plume, near the Reynolds Street source area, decreased in wells $33 \mathrm{H} 130(310 \mathrm{mg} / \mathrm{L}), 34 \mathrm{H} 424(320 \mathrm{mg} / \mathrm{L})$, and $33 \mathrm{H} 133$ $(230 \mathrm{mg} / \mathrm{L})$. The mean decrease in chloride concentration for 12 wells over the 1 -year period was $145 \mathrm{mg} / \mathrm{L}$.

A comparison of results from separate groundwater samples collected during October 2014 and October 2015, in six wells open to the LWBZ of the UFA, indicates a maximum increase in chloride concentration of $70 \mathrm{mg} / \mathrm{L}$ and a maximum decrease of $320 \mathrm{mg} / \mathrm{L}$ (fig. 5C). Near the Reynolds Street source area, within the central part of the chloride plume, decreases in chloride concentration ranged from $320 \mathrm{mg} / \mathrm{L}$ (well 34H402) to $20 \mathrm{mg} / \mathrm{L}$ (well 34H354). Decreases in chloride concentration were also evident near the industrial well fields, with an $80-\mathrm{mg} / \mathrm{L}$ decrease in well $34 \mathrm{H} 334$ south of Pinova and a 250-mg/L decrease in well 33H154, which is located east of the Brunswick Cellulose plant. The mean decrease in chloride concentration for the six wells was $124 \mathrm{mg} / \mathrm{L}$.
Due to increasing chloride levels in well 34H134, modifications were made to the well to reduce water inflow from the deeper part of the aquifer. The bottom of the well, between the depths of $942 \mathrm{ft}$ and $724 \mathrm{ft}$, was sealed with concrete grout, thereby eliminating water production from a 218 -ft zone that yields higher chloride water. Subsequently, a water sample collected by the USGS in October 2015 from the modified well $34 \mathrm{H} 560$ showed a decrease of $26 \mathrm{mg} / \mathrm{L}$ in the chloride concentration (fig. $5 \mathrm{~A}$ ) since the plugging of the lower zone, which indicates a slight reduction in the upward migration of chloride into the open interval of the well. Chloride concentrations have increased in well 34H134/34H560 from near background levels (20 to $30 \mathrm{mg} / \mathrm{L}$ ) during June $2000(32.0 \mathrm{mg} / \mathrm{L}$ ) to $96 \mathrm{mg} / \mathrm{L}$ for the sample collected during October 2015 (fig. 5B). This increase in chloride suggests either a lateral movement of chloride in the UWBZ from the plume or the continued upward migration of chloride from lower depths. In late 2009, well $34 \mathrm{H} 134 / 34 \mathrm{H} 560$ was equipped to monitor daily changes in specific conductance. Specific conductance is a surrogate for chloride concentration and is used to monitor the potential movement of saltwater into the freshwater zones of the UFA (Cherry and others, 2011).

Decreases in the chloride concentration in several wells open to the UPZ in the LFA suggest reduced upward flow from the LFA into the UWBZ and LWBZ of the UFA. The groundwater sample collected in October 2015 at well 34H391, which taps the UPZ of the LFA, had a chloride concentration of $2,430 \mathrm{mg} / \mathrm{L}$, indicating a decrease of $540 \mathrm{mg} / \mathrm{L}$ when compared with the sample taken in October 2014. Results from water samples collected from LFA well $34 \mathrm{H} 399$, which is open to a slightly deeper interval of the UPZ than well 34H391, indicated a chloride concentration of 5,530 $\mathrm{mg} / \mathrm{L}$ during October 2015 and a decrease of $130 \mathrm{mg} / \mathrm{L}$ over a 1 -year period. Well 33H188, which is open to the deeper FPZ of the LFA, had a chloride concentration of $11,500 \mathrm{mg} / \mathrm{L}$ during July 2013 . Results from a discrete groundwater sample collected from well 34H495 (location shown in fig. 2), at a depth of 2,720 ft (lower portion of FPZ) during August 2000, had a chloride concentration of $26,000 \mathrm{mg} / \mathrm{L}$, which is higher than the $19,000-\mathrm{mg} / \mathrm{L}$ chloride concentration of modern seawater (Hem, 1989; Falls and others, 2005).

A comparison of results from separate groundwater samples collected during June 2000 and October 2015, in 12 wells open to the UWBZ of the UFA, indicates a maximum increase in chloride concentration of $550 \mathrm{mg} / \mathrm{L}$ and a maximum decrease of $678 \mathrm{mg} / \mathrm{L}$ (fig. $5 B$ ). The maximum increase in chloride concentration was reported in well $33 \mathrm{H} 133$ $(550 \mathrm{mg} / \mathrm{L})$, east of the Brunswick Cellulose plant. Well $34 \mathrm{H} 424 \mathrm{had}$ a chloride increase of $230 \mathrm{mg} / \mathrm{L}$, which coincides with one of the two areas with the greatest chloride concentrations north of the Reynolds Street source area. The maximum decrease of $678 \mathrm{mg} / \mathrm{L}$ (well 34H469) was also located in the northern part of the chloride plume and may be the result of preferential flow paths and changes in local hydraulic head gradient caused by nearby pumping. Well 34H393, located within the Bay Street source area, had a decrease in its chloride concentration of $90 \mathrm{mg} / \mathrm{L}$. North of well 34H393, chloride concentrations decreased in wells $34 \mathrm{H} 112(230 \mathrm{mg} / \mathrm{L}), 34 \mathrm{H} 125$ $(317 \mathrm{mg} / \mathrm{L})$, and $34 \mathrm{H} 434(190 \mathrm{mg} / \mathrm{L})$. The mean decrease in chloride concentrations for 12 wells over the 16-year period (June 2000-October 2015) was $54 \mathrm{mg} / \mathrm{L}$. 
A. Upper water-bearing zone (UWBZ) of Upper Floridan aquifer (UFA) 2014 to 2015

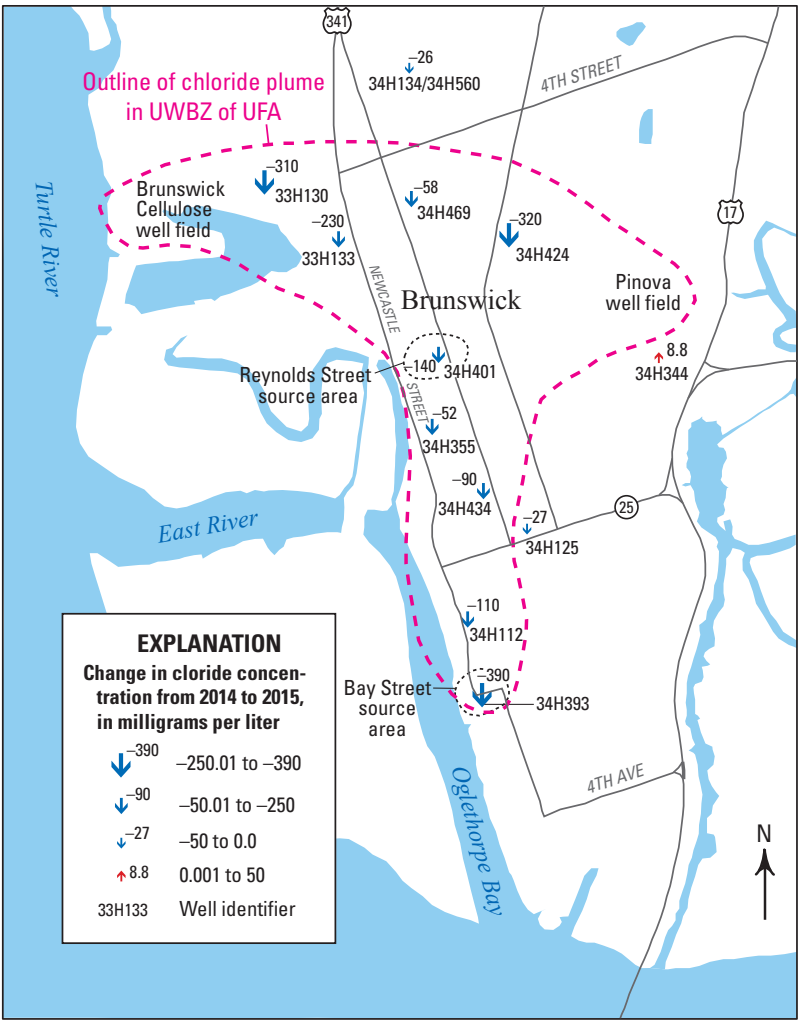

\section{Lower water-bearing zone (LWBZ) of UFA and Lower Floridan} aquifer LFA) 2014 to 2015

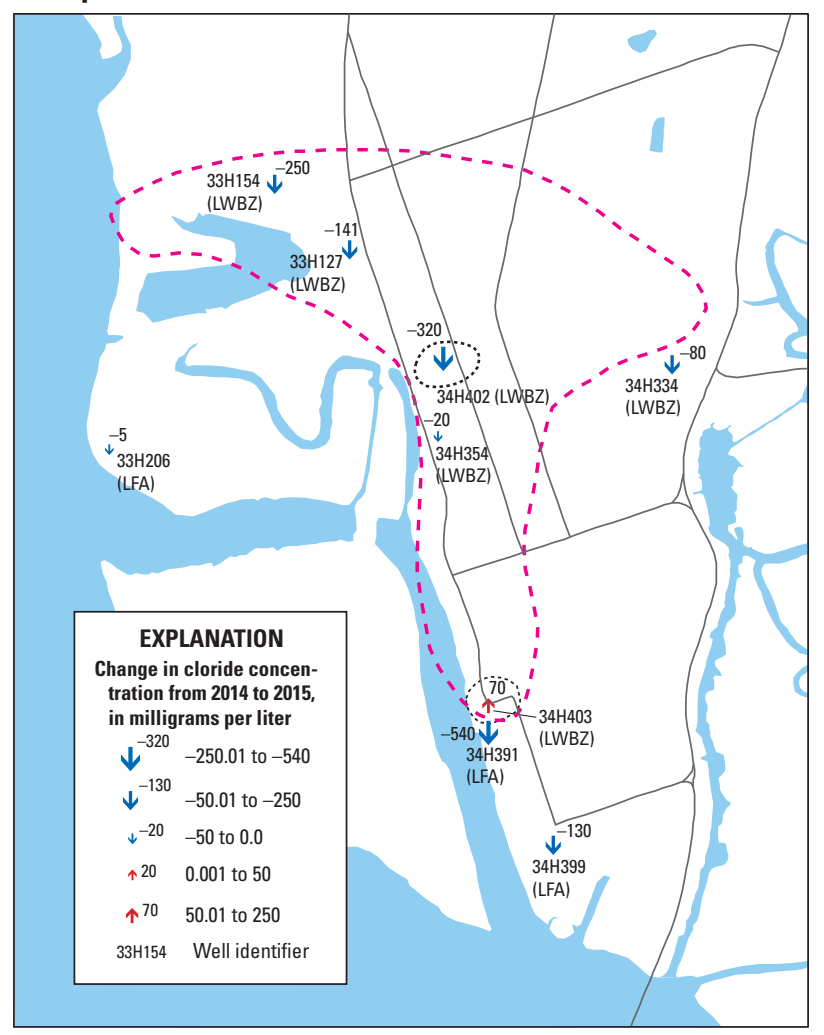

\section{B. UWBZ of UFA 2000 to 2015}

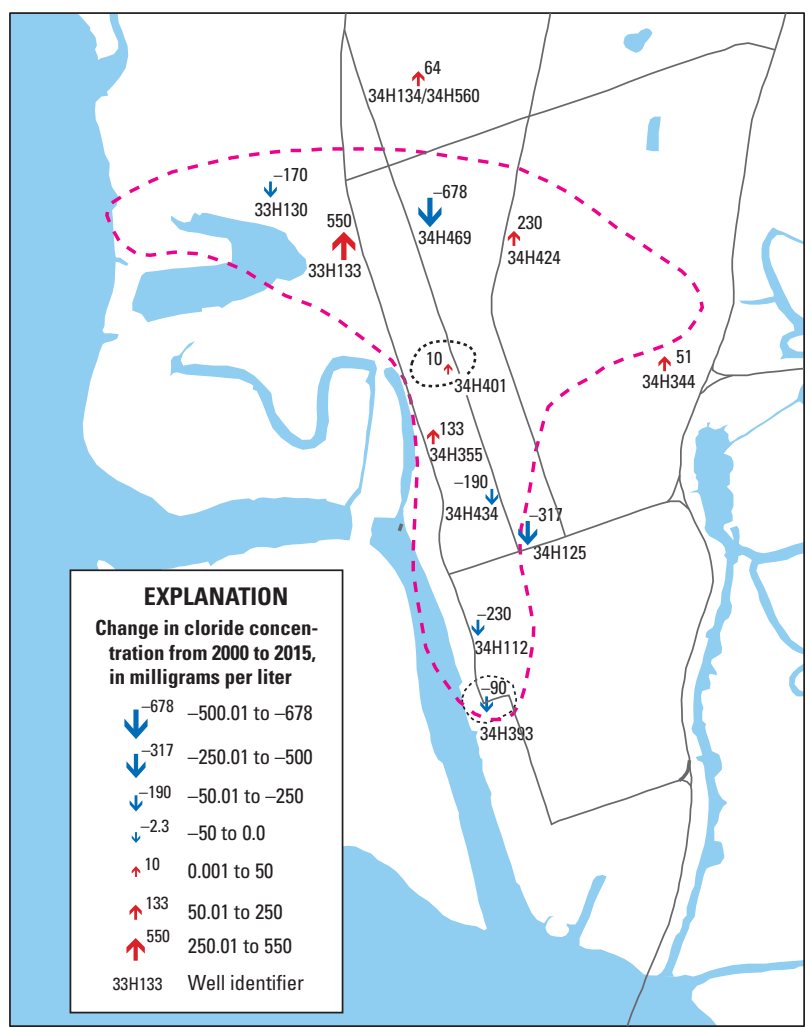

\section{LWBZ of UFA and LFA 2000 to 2015}

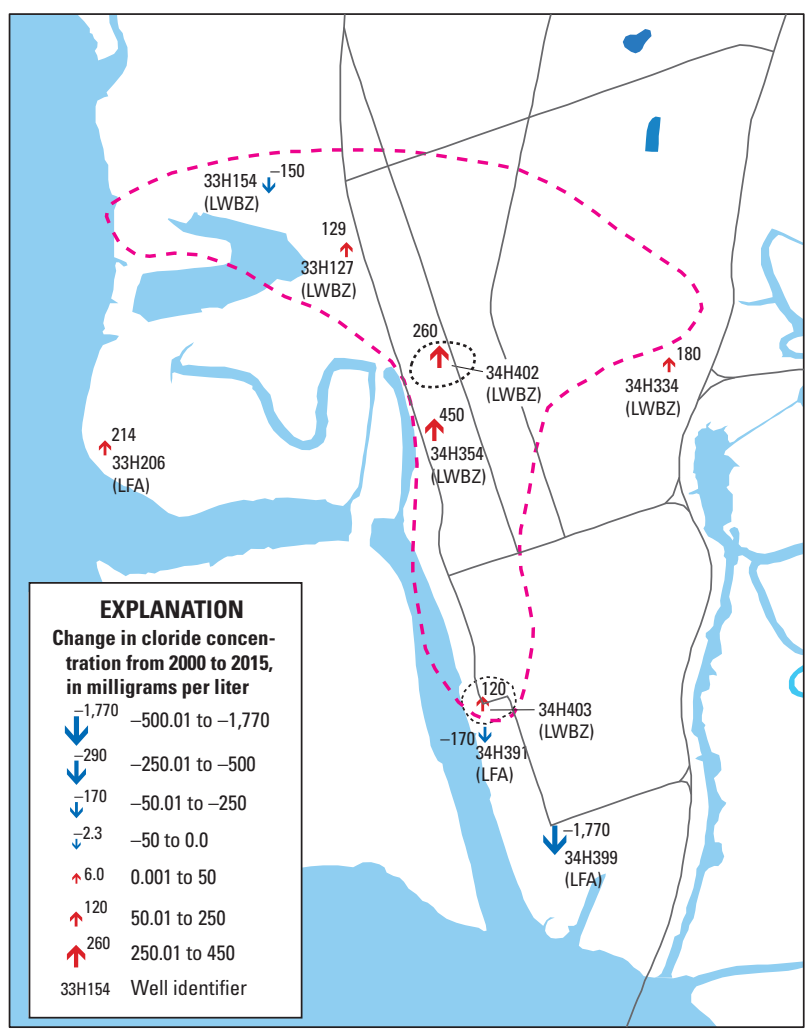

Figure 5. Change in chloride concentration in the Upper and Lower Floridan aquifers in the Brunswick area, Georgia. 
A comparison of results from separate groundwater samples collected during June 2000 and October 2015, in six wells open to the LWBZ of the UFA, indicates general increases in chloride concentration ranging from $120 \mathrm{mg} / \mathrm{L}$ (well 34H403) to $450 \mathrm{mg} / \mathrm{L}$ (34H354; fig. $5 \mathrm{D})$. The mean increase in chloride concentration in four wells $(33 \mathrm{H} 127,34 \mathrm{H} 402,34 \mathrm{H} 354$, and $34 \mathrm{H} 334$ ) located near the Reynolds Street source area was $255 \mathrm{mg} / \mathrm{L}$. The mean increase in chloride concentration for six wells open to the LWBZ of the UFA was $172 \mathrm{mg} / \mathrm{L}$. Increases in the chloride concentration in well 34H334 (180 mg/L) suggest the lateral movement of chloride in the LWBZ of the UFA outside the current inferred boundary of the chloride plume in the UWBZ of the UFA. The only decrease in chloride concentration in the LWBZ of the UFA over the 16-year period was the $150-\mathrm{mg} / \mathrm{L}$ decrease reported in well $33 \mathrm{H} 154$.

A comparison of results from separate groundwater samples collected during June 2000 and October 2015, in three wells open to the UPZ of the LFA, indicates an increase in the chloride concentration in well $33 \mathrm{H} 206$ of $214 \mathrm{mg} / \mathrm{L}$ and decreases of $1,770 \mathrm{mg} / \mathrm{L}$ in well $34 \mathrm{H} 399$ and $170 \mathrm{mg} / \mathrm{L}$ in well 34H391. These results suggest a continued vertical migration of chloride from the FPZ of the LFA into the UFA near the Brunswick Cellulose well field. These results also suggest a change in the vertical hydraulic head gradient near the Bay Street source area that has reduced chloride concentrations in wells 34H391 and 34H399. The chloride distribution within the LWBZ of the UFA and UPZ of the LFA are difficult to map because fewer wells are open to these zones.

Additional groundwater samples were collected from seven production wells at Brunswick Cellulose to assess the vertical movement of chloride near the Brunswick Cellulose well field (fig. 6). The seven active production wells tap different water-bearing zones of the UFA, with three wells open to the UWBZ of the UFA and four wells open to both the UWBZ and LWBZ of the UFA. The chloride concentrations in the three production wells open to the UWBZ of the UFA ranged from 18.5 to $75 \mathrm{mg} / \mathrm{L}$ and are located outside of the chloride plume area. The chloride concentrations in the four production wells open to the UWBZ and LWBZ of the UFA ranged from 176 to $1,000 \mathrm{mg} / \mathrm{L}$. In three of these four production wells, chloride concentrations exceeded the SMCL of $250 \mathrm{mg} / \mathrm{L}$, indicating a deterioration of water quality with depth and suggesting greater rates of lateral movement of chloride within the LWBZ.

Additional groundwater samples were collected from two production wells at the Pinova well field to assess the lateral movement of chloride in the UWBZ of the UFA near the well field. Numerous production wells at Pinova were originally constructed in the UWBZ and LWBZ, but open intervals tapping the LWBZ were plugged during the mid-1960s to improve water quality in the well field (Cherry and others, 2011). Results from the samples collected during October 2015 indicate a sharp transition in chloride concentration from near background levels of $16.9 \mathrm{mg} / \mathrm{L}$ in well $34 \mathrm{H} 450$, which is located outside the chloride plume area, to $533 \mathrm{mg} / \mathrm{L}$ in well $34 \mathrm{H} 413$, which is located near the center of the facility (fig. 6). These two wells are located approximately $1,360 \mathrm{ft}$ apart. The USGS well-cluster site located south of the Pinova well field has a well open to the UWBZ and another well open to the LWBZ of the UFA. Chloride concentrations from samples collected during October 2015 show chloride levels above background $(70 \mathrm{mg} / \mathrm{L})$ in well $34 \mathrm{H} 344$, which is open to the UWBZ, and elevated chloride levels $(1,180 \mathrm{mg} / \mathrm{L})$ in well $34 \mathrm{H} 334$, which is open to the LWBZ of the UFA.

\section{Water Chemistry of the Upper Floridan Aquifer}

Water samples were collected and analyzed for major ions from seven production wells tapping the UWBZ of the UFA and from six production wells tapping both the UWBZ and LWBZ of the UFA. The results of the analyses indicate that groundwater chemistry changes with depth in the UFA and approaches the composition of modern seawater in the FPZ of the LFA. Previous analyses performed by Falls and others (2005) show the isotopic composition of groundwater in the FPZ of the LFA to be fossil seawater trapped in the formation. The groundwater chemistry of the chloride plume in the UFA near downtown Brunswick indicates it is a mixture of about 10 to 20 percent of FPZ fossil seawater and 80 to 90 percent freshwater from the UFA.

A trilinear plot was used to classify the water type of the UWBZ and the LWBZ of the UFA based on major cation and anion compositions (Piper, 1944). The major ion compositions were plotted as a percentage of total milliequivalents per liter for the major cations and anions for 13 groundwater samples (fig. 7). The major ion compositions of groundwater from several depth intervals within the FPZ of the LFA and modern seawater are included to show potential sources (Hem, 1989; Falls and others, 2005). The trilinear plot indicates groundwater from the UWBZ of the UFA is a mix of cations, with calcium $\left(\mathrm{Ca}^{2+}\right)$ plus magnesium $\left(\mathrm{Mg}^{2+}\right)$ ranging from 74 to 85 percent, and the remaining 15 to 26 percent from sodium $\left(\mathrm{Na}^{+}\right)$.

Potassium $\left(\mathrm{K}^{+}\right)$is considered a minor component, with concentrations ranging from 1.7 to $2.2 \mathrm{mg} / \mathrm{L}$. The anion composition is a mix of sulfate $\left(\mathrm{SO}_{4}{ }^{2-}\right)$ plus chloride $\left(\mathrm{Cl}^{-}\right)$ranging from 54 to 71 percent, with the remaining 29 to 46 percent composed of bicarbonate $\left(\mathrm{HCO}_{3}^{-}\right)$.

The most noticeable change, with the introduction of groundwater from the LWBZ of the UFA, is the increase of the anion chloride and the cation sodium, which is a major component of trapped fossil seawater from the FPZ of the LFA. The trilinear plot indicates mixed groundwater from wells open to the UWBZ and LWBZ of the UFA is composed of 33 to 61 percent sodium and 39 to 67 percent calcium plus magnesium. The anion composition is dominated by sulfate plus chloride ranging from 71 to 95 percent and 5 to 29 percent bicarbonate. The trilinear plot shows groundwater transitions, along with increased depth, from a calcium-magnesiumchloride-sulfate type to a chloride type. The groundwater chemistry of two samples collected from deep well 34H495 and a sample from modern seawater were used as endmembers or potential sources. The composition of modern seawater is 78 percent sodium, 22 percent calcium plus magnesium, and 99 percent sulfate plus chloride, with chloride and sulfate concentrations of 19,000 and 2,700 mg/L, respectively (Hem, 1989). Sprinkle (1989) attributed the major sources of dissolved constituents (common ions) in the FAS to the dissolution of calcite $\left(\mathrm{CaCO}_{3}\right)$, dolomite $\left(\mathrm{CaMg}\left(\mathrm{CO}_{3}\right)_{2}\right)$, and gypsum $\left(\mathrm{CaSO}_{4} \cdot 2 \mathrm{H}_{2} \mathrm{O}\right)$ and the solubility of calcite $\left(\mathrm{HCO}_{3}^{-}\right)$. Chloride and sodium increase where freshwater and saltwater mix. 


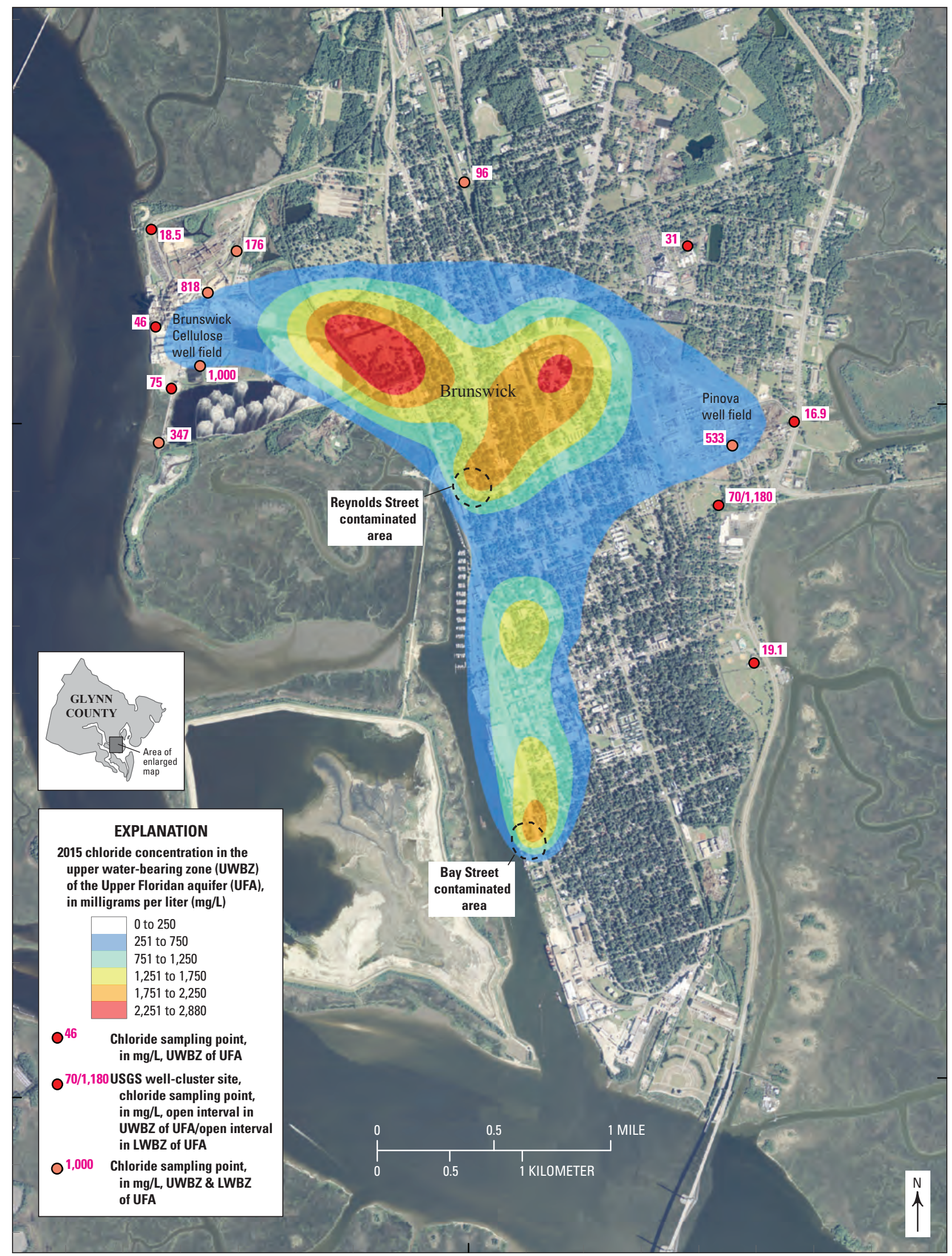

Image from National Agriculture Imagery Program 2010 east digital ortho quarter quad tiles, available via https://www.fsa.usda.gov/programs-and-services/aerial-photography/imagery-programs/naip-imagery/index

Figure 6. Chloride concentration in the upper water-bearing zone (UWBZ) of the Upper Floridan (UFA) aquifer during October 2015 and chloride concentration at select production wells open to the UWBZ of the UFA and UWBZ and lower water-bearing zone (LWBZ) of the UFA in the Brunswick area. 
Figure 7. Major cation and anion compositions of water samples from the upper and lower water-bearing zones of the Upper Floridan aquifer, the Fernandina permeable zone of the Lower Floridan aquifer, and modern seawater sample (Hem, 1989; Falls and others, 2005).
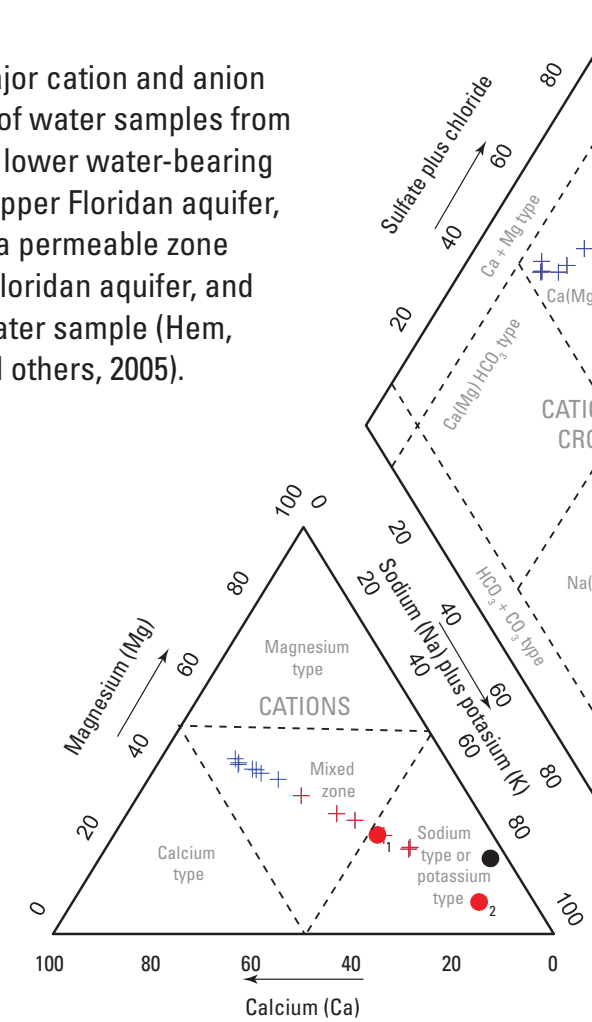

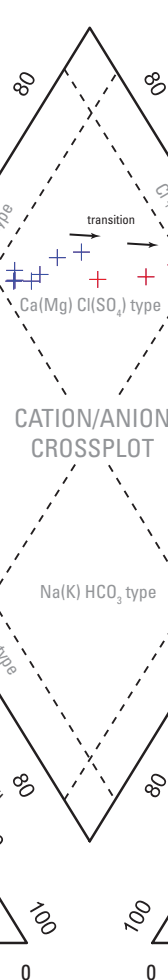

EXPLANATION

Groundwater samples from
Upper Floridan aquifer
+ Upper water-bearing zone
+ Upper and lower water-bearing zones
Groundwater samples from
Fernandina permeable zone
of Lower Floridan aquifer
Brunswick, 34H495 (depth of sample:
2,084 feet)
2 Brunswick, 34H495 (depth of sample:
2,720 feet)
Modern seawater (Hem, 1989)

PERCENT OF TOTAL MILLIEQUIVALENTS PER LITER

\section{References Cited}

Cherry, G.S., Peck, M.F., Painter, J.A., and Stayton, W.L., 2011, Groundwater conditions in the Brunswick-Glynn County area, Georgia, 2009:

U.S. Geological Survey Scientific Investigations Report 2011-5087, 58 p. [Also available at http://pubs.usgs.gov/sir/2011/5087/.]

Falls, W.F., Harrelson, L.G., Conlon, K.J., and Petkewich, M.D., 2005, Hydrogeology, water quality, and water-supply potential of the Lower Floridan aquifer, coastal Georgia, 1999-2002: U.S. Geological Survey Scientific Investigations Report 2005-5124, 89 p., 1 pl. [Also available at http://pubs.usgs.gov/sir/2005/5124/.]

Georgia Environmental Protection Division, 1997, Secondary Maximum Contaminant Levels for drinking water-Environmental Rule 391-3-5-19, revised October 1997: Official Code of Georgia Annotated Statutes, Statute 12-5-170 (Georgia Safe Drinking Water Act), variously paged.

Hamrick, M.D., and Cherry, G.S., 2015, Monitoring saltwater contamination in the Upper Floridan aquifer, Brunswick, Georgia, in McDowell, R.J., Pruitt, C.A., Bahn, R.A., eds., Proceedings of the 2015 Georgia Water Resources Conference, held April 28-29, 2015: The University of Georgia, Athens.

Hem, J.D., 1989, Study and interpretation of the chemical characteristics of natural water (3d ed.): U.S. Geological Survey Water-Supply Paper 2254, 263 p. [Also available at https://pubs.er.usgs.gov/publication/wsp2254.]

Johnston, R.H., Krause, R.E., Mayer, F.W., Ryder, P.D., Tibals, C.H., and Hunn, J.D., 1980, Estimated potentiometric surface for the Tertiary limestone aquifer system, Southeastern United States, prior to development: U.S. Geological Survey Open-File Report 80-406, 1 map sheet. [Also available at https://pubs.er.usgs.gov/publication/ofr80406.]

Jones, L.E., 2001, Saltwater contamination in the Upper Floridan aquifer at Brunswick, Georgia, 1999-2000, in Hatcher, K.J., ed., Proceedings of the 2001 Georgia Water Resources Conference, March 26-27, 2001: Athens, Ga., University of Georgia, Institute of Ecology, p. 644-647. [Also available at https://smartech.gatech.edu/handle/1853/44296.]

Jones, L.E., Prowell, D.C., and Maslia, M.L., 2002, Hydrogeology and water quality (1978) of the Floridan aquifer system at U.S. Geological Survey Test Well 26, on Colonels Island, near Brunswick, Georgia: U.S. Geological Survey Water-Resources Investigations Report 02-4020, 44 p. [Also available at http://pubs.usgs.gov/wri/2002/wri02-4020/.]

Krause, R.E., and Randolph, R.B., 1989, Hydrology of the Floridan aquifer system in southeast Georgia and adjacent parts of Florida and South Carolina: U.S. Geological Survey Professional Paper 1403-D, 65 p., 18 pl.

ISSN 2327-6932 (online)
Maslia, M.L., and Prowell, D.C., 1990, Effects of faults on fluid flow and chloride contamination in a carbonate aquifer system: Journal of Hydrology, v. 115, nos. 1-4, p. 1-49. [Also available at http://pubs.er.usgs.gov/publication/70016336.]

Miller, J.A., 1986, Hydrogeologic framework of the Floridan aquifer system in Florida and in parts of Georgia, Alabama, and South Carolina: U.S. Geological Survey Professional Paper 1403-B, 91 p., 33 pl. [Also available at http://pubs.er.usgs.gov/publication/pp1403B.]

Piper, A.M., 1944, A graphic procedure in the geochemical interpretation of water analyses: American Geophysical Union Transactions, v. 25, p. 914-923. [Also available at http://dx.doi.org/10.1029/tr025i006p00914.]

Sprinkle, C.L., 1989, Geochemistry of the Floridan aquifer system in Florida and parts of Georgia, South Carolina, and Alabama: U.S. Geological Survey Professional Paper 1403-I, 105 p. [Also available at https://pubs.er.usgs.gov/ publication/pp1403I.]

U.S. Census Bureau, 2015, State \& county quickfacts - Glynn County, Georgia: U.S Census Bureau Web site, accessed May 11, 2016, at http://www.census.gov/ quickfacts/table/PST045215/13127,00.

U.S. Environmental Protection Agency, 2000 (revised), Maximum Contaminant Levels (Part 143, National Secondary Drinking-Water Regulations): U.S. Code of Federal Regulations, Title 40, parts 100-149. [Also available at https://www.epa.gov/sites/production/files/2015-11/documents/howeparegulates_cfr-2003-title40-vol20-part143.pdf.]

U.S. Environmental Protection Agency, 2003, Contaminant Candidate List (CCL) and Regulatory Determination, accessed May 11, 2016, at https://www.epa.gov/ccl/regulatory-determination-1-support-documents-sodium.

U.S. Geological Survey, 2016, National Water Information System-Web interface, accessed September 28, 2016, at http://dx.doi.org/10.5066/F7P55KJN.

Wait, R.L., 1965, Geology and occurrence of fresh and brackish water in Glynn County, Georgia: U.S. Geological Survey Water-Supply Paper 1613-E, 94 p. [Also available at http://pubs.er.usgs.gov/publication/wsp1613E.]

Wait, R.L., and Gregg, D.O., 1973, Hydrology and chloride contamination of the principal artesian aquifer in Glynn County: Georgia Department of Natural Resources Hydrologic Report, 93 p.

Williams, L.J., and Kuniansky, E.L., 2015, Revised hydrogeologic framework of the Floridan aquifer system in Florida and parts of Georgia, Alabama, and South Carolina (ver. 1.1, March 2016): U.S. Geological Survey Professional Paper 1807, 140 p., 23 pls. [Also available at http://dx.doi.org/10.3133/pp1807.]

Suggested citation: Cherry, G.S., and Peck, M.F., 2017, Saltwater intrusion in the Floridan aquifer system near downtown Brunswick, Georgia, 1957-2015: U.S. Geological Survey Open-File Report 2017-2010, 10 p., https://doi.org/10.3133/ofr20171010. 